\title{
Tahsin and Tahfidz Learning System at Integrated Islamic Elementary School (SDIT) Insan Madani During the Pandemic Covid-19
}

\author{
*Afiful Ikhwan ${ }^{1}$, Saiful Anwar ${ }^{2}$, Nashikhatun Mahmudah ${ }^{3}$ \\ 1,2,3Universitas Muhammadiyah Ponorogo, J1. Budi Utomo No.10, Ponorogo, Indonesia \\ *afifulikhwan@gmail.com
}

\begin{abstract}
Integrated Islamic Primary School (SDIT) Insan Madani Madiun has implemented online learning in the Even Semester of the 2019/2020 Academic Year to keep the learning going during the Covid-19 pandemic. This study aims to analyze the learning process of tahsin and tahfidz during the Covid-19 pandemic. This type of research is descriptive qualitative; indirect interviews carried out data collection due to the effects of the Covid-19 pandemic. This study indicates that learning uses existing social media with a system, namely the provision of learning videos, then students make daily Tahsin and Tahfidz deposits via WhatsApp (WA). Some of the obstacles include consuming a lot of quotas and weak internet networks. The learning process still needs to be optimized, and it is necessary to evaluate the improvement of online learning in the next period.
\end{abstract}

Sekolah Dasar Islam Terpadu (SDIT) Insan Madani Madiun telah memberlakukan pembelajaran daring pada Semester Genap Tahun Akademik 2019/2020 sebagai upaya pembelajaran tetap berjalan di masa pandemi Covid-19. Penelitian ini bertujuan untuk menganalisis proses pembelajaran tahsin dan tahfidz di masa pandemi Covid-19. Jenis Penelitian ini adalah deskriptif kualitatif, pengambilan data dilakukan dengan wawancara secara tidak langsung dikarenakan efek dari pandemi Covid-19. Hasil penelitian ini menunjukkan bahwa pembelajaran menggunakan media sosial yang ada dengan sistem yaitu diberikannya video pembelajaran kemudian siswa melakukan setoran tahsin dan tahfidz setiap harinya via WhatsApp (WA). Beberapa kendala diantaranya banyak menghabiskan kuota serta jaringan internet yang lemah. Proses pembelajaran masih perlu untuk terus dioptimalkan dan perlu untuk dilakukan evaluasi demi perbaikan pembelajaran daring pada periode berikutnya.

Keywords: Tahsin, Tahfidz, Learning System, Covid-19.

Received: December 30, 2020; Revised: January 13, 2021; Accepted: April 1, 2021

\section{INTRODUCTION}

Education is something that is needed in a person's life both now and in the future. Education is an essential aspect for society, the nation and even the state. In Indonesia, every child's compulsory education is 12 years, consisting of 6 years of elementary school, three years of senior high school, and three years of vocational education or 
senior high school (SMA). Today's education is no longer only studying general subjects but also about religious education.

In Islam, every individual is required to study and practice his religious guidelines, namely the Koran. Al-Qur'an is the holy book as a miracle of the Prophet Muhammad, which is the first and foremost holy book that Muslims must study. The ease of descending the Qur'an gradually for 22 years, 2 months, 22 days or an average of 23 years shows that the gradual wisdom of revelation is a sign of encouraging the growth of memorization (Anwar, 2021). Rasulullah is a figure who carefully memorizes and memorizes the entire Koran by remembering to be an example for his people. Learning the Qur'an is an obligation for every Muslim, as well as teaching it. Studying the Qur'an correctly and adequately according to the rules that apply therein can lead a person to a life that is pleased by Allah SWT. One of them is learning the meaning and meaning of each verse and memorizing the Koran correctly and adequately.

The implementation of Al-Qur'an Education for children is the first basis of Islamic education, so that the teaching must be prioritized from an early age (Firdaos and Ahmad, 2018). As Sa'ad Riyadh put it that whoever wants to build a strong relationship and is filled with the satisfaction of love and respect between the child and the Qur'an must start from an early age and pay great attention to it. From the expression conveyed by Sa'ad Riyadh, we can conclude that if we want to build a strong relationship filled with love and respect, we should start by teaching the Koran to children as early as possible because it cannot be denied that children at their age early to catch knowledge faster, where his brain, attention, and powers of memory are still very sharp (Ikhwan, 2019).

In studying the Qur'an, there are several specific and specific terms such as tahfidz, tahsin, and tilawah (Obeng, 2013). These three terms are related to each other when studying the Qur'an. Tahfidz means memorizing more than that is tadabbur which means deepening or understanding. So tahfidz is not just memorizing but also learning its meaning and content. Tahsin means to improve, decorate, enhance, beautify, or make better than the previous state. At the same time, tilawah is reading or reading. Recitation is reading the Koran with a reading that reveals the letters and being careful in devoting it so that it is easier to understand the meanings contained therein (Ariani and Realita, 2017).

SDIT Insan Madani is an integrated Islamic school that uses the Al-Quran teaching method based on the wafa method. The wafa method is a method that further optimizes the right side of the brain. The purpose of using the wafa method is to understand the makharijul letters and the rules of Tajweed knowledge with the rhythm of the hijaz song (Budiman, 2017).

By looking at the current world conditions that feel the impact of the Covid-19 pandemic, SDIT Insan Madani has also experienced it. Although the beginning of this virus's emergence had been about a year ago, community activities have not yet entirely run typically. Several companies with special permits have started to obtain access to operate again after enacting the PSBB and the emergence of a new average era (Suryani, Boy and Ramadhani, 2020). However, the world of education currently has no definite news, so the learning process is still using the internet or online media. The existence of distance learning or online results in an inefficient learning process such as the one at SDIT Insan Madani, especially in learning tahsin and tahfidz AlQur'an, the hallmarks and culture of these educational institutions. 
According to Yeni Yuliana, in her writing, internet media use during online learning is the only way that can be taken (Yuliana, 2020). E-Learning described in this article provides a vital role and a significant function in this course. So far, there have been many shortcomings and weaknesses, such as limited space and time in the teaching and learning process through E-learning, prioritising learning efficiency to receive teaching. Which is complete, although it does not have to be face to face, can also be accessed anywhere, anytime, according to the assignment given by the educator, usually scheduled with a specified time limit (Moore, Dickson-Deane and Galyen, 2011).

Changes in learning patterns currently appear to be massive at all education levels due to the Covid-19 pandemic. As in Zainal Abidin's research, project-based online learning is one solution for teaching and learning activities amid the Covid-19 pandemic. There are at least 12 other free applications as media and online learning resources that can be used in the Covid-19 pandemic, namely Rumah Belajar, Meja Kita, Icando, Indonesia X, Google for Education, Smart Class, Microsoft Office 365, Quipper School, Ruangguru, Sekolahmu, Zenius and Cisco Webex. This study describes one of the learning approaches that can maximize online learning as projectbased learning. This learning provides students opportunities to learn concepts in depth while also improving their learning outcomes (Arizona, Abidin and Rumansyah, 2020).

\section{Learning Tahsin and Tahfidz}

Learning comes from learning, and learning means someone who is trying to acquire intelligence, knowledge or knowledge that has never been owned before. So that in learning to change someone from ignorance to knowledge, from not understanding to understanding, and so on. Learning is an activity or process to acquire knowledge, improve skills, improve behaviour, attitudes, and strengthen personality.

According to Hamalik, learning reinforces behaviour through behaviour and changes individual behaviour through interaction with the surrounding environment. Learning is a process of not knowing to know. The process from which an impersonal person becomes a person with a good personality or the process of improving behaviour through interaction with the environment (Hamalik, 2005).

Learning is at the core of an educational process, with educators acting as the leading educational agent. The learning process is not just a transfer of knowledge from educators to students, but more than that, learning is a process of interaction between educators and students (Ikhwan, 2018). Among the learning methods in studying the Koran is tahsin, which is how to read the Koran properly and correctly by using the principles contained in the science of tajwid and improving and improving the reading. Ali M vomar explained that the meaning of "tahsin" is in line with tajwid's essence, namely improvement, perfection; the purpose of tahsin is much broader in scope than tajwid. This is because in tahsin, in addition to using the tajwid principles, it also tries to improve and beautify the reading with a sweet voice. If someone learns the science of tahsin, then at the same time, they can learn the science of recitation (Sugiati, 2016).

Thus, learning tahsin cannot be separated from the knowledge of tajwid because, without the application of tajwid, it is impossible to read the Qur'an properly, correctly and beautifully. It means that the application of tajwid is a necessity that must be used in tahsin. 
While tahfidz comes from lafadz hafadha-yahfadhu, hifdhan, "to maintain and memorize." The meaning of memorizing, in reality, is reading over and over again so that you recite from one verse to the next, from one letter to the next and so on. Meanwhile, according to Abdul Aziz Abdul Rauf the definition of tahfidz is "the process of repeating something either by reading or listening." Any work that is repeated often will be tahfidz (Ferdinan and Ibrahim, 2018).

According to Baso Hasyim, Al-Qur'an is the word of Allah SWT that was sent down to Muhammad's heart through the revelation-Jibril as the intermediary gradually in the form of verses and letters during the apostolic phase (23 years), starting with surah AlFatihah and ending with Surah An-Nas, conveyed absolutely, as absolute proof of miracles of the truth of the message of Islam (Hasyim, 2013).

As mentioned in the question and answer in a study, Ustadz Rusmanto touched on the difference between the meaning of the Qur'an and the Mushaf. He asked why is it called Al-Qur'an because it sounds, that means someone has to read and recite it (chant). This is also the command of why the Qur'an should be read or pronounced. Because if it doesn't sound, it's called Mushaf (sheet) (Rusmanto, 2020).

\section{METHOD}

This paper uses a qualitative descriptive research method, with more emphasis on the type of field research. Researchers try to describe a symptom, event, event that is happening now. Descriptive research is a form of research proposed to explain existing phenomena. These phenomena include conditions, activities, characteristics, changes, relationships, similarities, and differences between one phenomenon and another. Data obtained by interview and observation of the location. This research's location is an educational institution that uses the tahsin and tahfidz learning systems at SDIT Insan Madani, Madiun. This study's population were all tahsin and tahfidz teachers at SDIT Insan Madani, totalling six teachers. This study's sample was 5 grade VI students of SDIT Insan Madani, Madiun district.

\section{RESULT AND DISCUSSION}

\section{Pandemics Change the Paradigm of Learning}

The Covid-19 pandemic is currently still an obstacle to life, including in the world of education. In real life, the learning system in schools has become less efficient in a pandemic face. Face-to-face learning was eliminated and replaced with online learning due to implementing the government's physical distancing policy. Such knowledge certainly requires the use of information technology, one of which is cell phones. So that guardians or parents accompany the children's learning process as a companion when their child is learning.

The online learning system is a direct learning system without face to face between educators and students, but it is carried out online. Teachers must ensure teaching and learning activities continue, even though students are at home. The solution, teachers are required to be able to design instructional media by utilizing online media.

Distance learning systems must be carefully prepared because distance learning is something new in education during the pandemic. The online learning system is 
certainly different from when face-to-face learning takes place. The level of difficulty and effectiveness is undoubtedly higher. Therefore, in this case, an educator must have IT (technology) skills that allow learning to occur even without face to face.

Some applications make online learning more accessible, such as zoom meetings, google classroom, google meet, or other media as teaching media. You can also use the YouTube application to upload learning videos. Apart from that, the WhatsApp application can also be used as an online learning medium. Whatsapp is the simplest medium that makes it easy for educators to learn online. Because WhatsApp is familiar to some parents, so it is suitable for beginner online students. Whatsapp operation is effortless and easily accessible to students.

Meanwhile, educators can improve their ability to master other media by using various online learning applications. Thus, the teacher can ensure students take part in learning simultaneously, even though in different places. In addition to the availability of learning applications, the Ministry of Education and Culture also provides free learning quotas for teachers and students, of course, this will facilitate learning and ease the burden on the guardians of students (Shodiq and Zainiyati, 2020).

\section{Online Learning System The Ultimate Solution}

An online learning system is imperfect if it does not support the internet network. An Internet network connection is one of the obstacles faced by all students who live far from the reach of internet access. Another obstacle that may occur is the sometimes unstable cellular network due to geographical conditions that are still far from the internet signal's reach, so the learning process is ineffective. This is a problem that many students take in online learning, so that the implementation is not optimal. Also, some problems occur because parents cannot accompany their children during online learning. Because parents who have jobs and professions that cannot be left behind and a child is not given to hold their cellphone. As a result, the child cannot participate in online learning to the fullest.

Obstacles with the existence of a distance learning system are not only felt by students, many parents, guardians of students, are often not strong enough to control their emotions because getting their children is challenging to manage so that parents cannot stand the behaviour of their children and want their children to return to school immediately. The positive thing is that this incident gives parents awareness that educating children is not easy, it requires very high knowledge and patience. Similar incidents should also raise awareness for parents to know how to guide their children in learning. After gaining this experience, it is hoped that parents will learn how to educate their children at home.

Distance learning systems are not as effective as face-to-face learning activities. The material can be explained directly and more completely, even more, accessible to understand face to face. Meanwhile, the material presented in online learning is not necessarily understood by students. Based on the experience of teaching online, this system is only effective for giving assignments (Cavus, 2015).

Almost all educational institutions throughout Indonesia have implemented a distance learning system. One of the main reasons is the limitation of direct relationship interactions to prevent contracting the Covid-19 virus. Starting from the level of early childhood education, primary education, middle to high school. It has even been carried out by schools in various countries affected by the Covid-19 pandemic. 
Because this is the Ministry of Education and Culture's policy to break the chain of the spread of Covid-19, this was also done by one of the integrated Islamic elementary schools (SDIT) in Magetan, East Java.

\section{Integration of General and Religious Education}

SDIT Insan Madani is an elementary school that combines two education systems, namely general education and religious education, developing intellectual (fikriyah), emotional (ruhiyah) and physical (jasadiyah) potential, as well as the participation of guardians or parents who are also considered as parties who have the duty and responsibility towards the world of education.

SDIT Insan Madani is an educational institution with an Islamic education concept based on the Qur'an and Sunnah. In implementing education, SDIT Insan Madani combines general education with religious education into a curriculum fabric. All subjects and all school activities cannot be separated from the teachings and messages of Islamic values.

The lessons provided in SDIT Insan Madani include general basic education and primary religious education, such as Islamic Religious Education (PAI), Citizenship Education (PKN), Indonesian, Mathematics, Natural Sciences (IPA), Social Sciences (IPS), Cultural Arts, Physical Education and Health (Penjaskes). While subjects related to Islam and included in the local content category have Akidah Akhlak, Qur'an Hadith, Fiqh, Tareqh (SKI), Arabic, English, Tahfidz, Tahsin, and Computers. With the density of general subjects plus the integration of Islamic education values in learning, SDIT Insan Madani applies the concept of full-day school. Students in school require a longer time than schools in general.

SDIT Insan Madani is under the Insan Madani Mulia foundation and has been inaugurated in 2010. The learning of tahsin and tahfidz has become a flagship program at SDIT Insan Madani. It is even unique as an attraction for parents or guardians in choosing educational institutions based on Integrated Islam. SDIT Insan Madani has memorized targets when graduating by taking exams before graduation. Of course, this will be a matter of pride for both themselves and the students' parents.

Learning tahsin and tahfidz are perfectly scheduled every day at SDIT Insan Madani. However, with the Covid-19 Virus and government regulations that require face-toface learning not to be implemented and replaced with distance learning, learning tahsin and tahfidz is done online as other subjects. Of course, educators must work extra to prepare all distance learning needs online (Assingkily, 2019).

\section{Implementation of Online Learning at SDIT Insan Madani}

Learning tahsin and tahfidz at SDIT Insan Madani during the pandemic was carried out using Whatsapp social media. The selection of learning media is motivated by the ease of access to the media application compared to other application media. Also, the WhatsApp application is familiar to many guardian parents, whose operation is effortless. The online learning system for tahsin and tahfidz at SDIT Insan Madani, where educators provide material by making a learning video, theories about tahsin and tahfidz materials are sent WhatsApp group. If there are questions from students or parents, guardians can use voice notes (Widyastri and Iskandar, 2020).

Instructional videos or voice notes that have been sent, students can study them at home with the guardian's parents' assistance. Even though learning is not carried out 
by going to school and face to face, students still must deposit memorization as usual while still learning face-to-face. It's just that with different media. Students make tahsin and tahfidz deposits via WhatsApp via voice notes, live video when reciting rote and once a month via video calls. After a deposit, educators provide comments and input or suggestions so that students can correct their mistakes so that they find perfection in studying the Qur'an.

The procedure for Mid-Semester Assessment (PTS) or Final Semester Assessment (PAS) is carried out by making a video call according to the achievement during the semester during the tahsin assessment, while in the tahfidz review, it is done by depositing the memorization that is achieved during each semester through voice notes. The indicators of taking the value of tahsin include paying attention to tajwid, sifatul-huruf and makharijul-huruf, while for the assessment of tahfidz paying attention to fluency, recitation and makharijul-huruf (Sudiarjo, Mariana and Nurhidayat, 2015).

The indicator of the success of learning tahsin and tahfidz at SDIT Insan Madani is the discipline of daily deposit activities according to a predetermined schedule. So students make tahsin deposits when the tahsin schedule and memorization deposits when the tahfidz program. Educators will provide an assessment one by one from the warranties of students, provide criticism and suggestions to students who are deemed incorrect in pronouncing the recitation of tajwid and makharijul-huruf.

Constraints in the distance learning at SDIT Insan Madani, especially in learning tahsin and tahfidz, include educators feeling overwhelmed, some students do not make deposits on time, because the cellphones used to belong to their parents, and are brought to work, so they just waiting for his parents to come home from work, even though the working hours of the tahsin and tahfidz teachers are around 5 hours each day. Another obstacle that often occurs is that sometimes children forget not to make deposits with the cellphone facility because of the fun playing games. The quota runs out quickly, the connection is terrible, and the cellphone is easily damaged because most of the garbage files are piling up. These learning process constraints make SDIT Insan Madani provide solutions such as providing free internet quota data packages for educators and students.

\section{Learning Model and the Role of Tahsin Tahfidz Teachers at SDIT Insan Madani}

The learning model of tahsin and tahfidz at SDIT Insan Madani uses the wafa' reading method, which is a method of learning to read the Qur'an using the right side of the brain, which is made easy and fun for children. The wafa' method is an effective and exciting method of knowing and learning the Qur'an by the times. The concept of understanding the wafa' method starts from understanding, then practising. One of the methods of learning is storytelling so that students do not get bored quickly and are always excited about learning the Qur'an.

Educators are one of the essential elements in the world of education. Educators are not only transferring knowledge to students, but an educator must also be able to have professional abilities in all fields of education, who are well educated and trained and have unique skills and expertise in the field of education so that they can produce the next generation of the nation by educational goals. Every educator must continuously improve their educational power, knowledge, attitudes, and skills. A professional can answer the challenges, wants and needs of community development. 
Human resources with quality, faith, purity, knowledge and understanding of technology are born from the womb of an educational institution, in which there are professional educators. An educator is responsible for the survival of a nation, where an educator's task is to prepare a generation to become a future leader through the educational path.

According to the minister of education and the Republic of Indonesia's culture, Nadiem Makarim said educators must own three competencies: critical thinking, collaboration, and problem-solving. These three important competencies should also be conveyed to students to create a quality education (Kemendikbud, 2020).

Professional and quality educators are needed in the world of education. In this case, of course, the tahsin and tahfidz educators' quality at SDIT Insan Madani are professional and qualified educators. Because of teachers' acceptance at these institutions through selection, such as interviews, they are reading the Koran, rote tests and others.

SDIT Insan Madani has eight professional educators, 2 of whom are in a trial process for several months to see their seriousness and professionalism. An educator's quality is seen from conveying the material and its ability to understand students and the material to be delivered.

According to the data results from a grade VI student of SDIT Insan Madani, good educators are easy to convey material so that the material is easy to understand and close to students. Educators' approaches to students further add to the impression of intimacy and enthusiasm for students because they feel more cared for so that the learning process is more enjoyable and easy to understand.

Being an educator that students like is something that all educators do not quickly obtain. It takes special efforts that must be done to attract attention and make a positive impression on students. Educators, to be liked by students, must be able to build a pleasant atmosphere, be able to act as a second parent, position themselves as friends in learning, have a good personality, have an attitude of affection, have a high sense of patience, give freedom, so they don't feel stressed while studying, an educator must also be able to be a listener and mediator.

The reason for taking the sample from students of class VI SDIT Insan Madani is because grade VI students are the biggest students and perhaps the students who understand the most when interviewed. Besides that, grade VI students have experienced being taught and guided by all educators, tahsin and tahfidz.

Table 1. Tahsin and Tahfidz Teacher Values

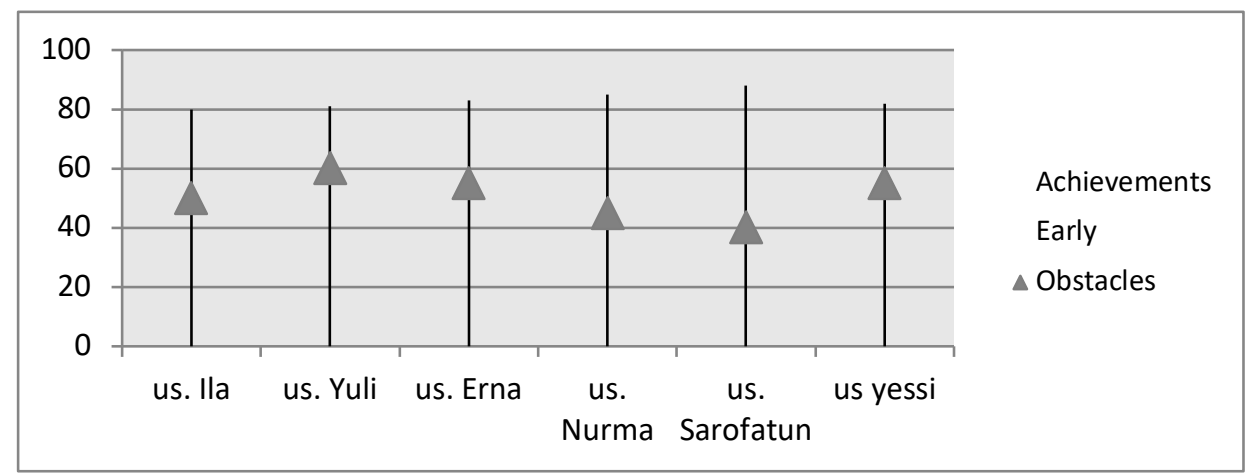

(Source: SDIT Insan Madani Data) 
The table above results from data processing obtained on the level of success and obstacles experienced in learning tahsin and tahfidz at SDIT Insan Madani during the Covid-19 pandemic. The table provides information that learning tahsin and tahfidz, even though it is not entirely successful with distance learning through WhatsApp media, is considered successful for these achievements because it can overcome obstacles during learning with significant results. It can also be concluded that in overcoming teaching methods or methods that are considered new, educators can adjust quickly, in other words, educators at SDIT Insan Madani have professional educators, where from time to time, if they experience an increase it will become Educational institutions that have their uniqueness and advantages from other educational institutions, besides having excellent learning programs for tahsin and tahfidz SDIT Insan Madani also has outstanding and professional educators.

\section{CONCLUSION}

The online learning system (in a network) is a distance learning system. Without having face-to-face meetings, educators and students can carry out learning. SDIT Insan Madani is an integrated-based Islamic school. The uniqueness of this institution is that it has excellent tahsin and tahfidz programs. As government regulations in effect during the Covid-19 pandemic, educational institutions carry out a natural learning process without face to face, SDIT Insan Madani continues to carry out this excellent program by implementing an online system. The program has memorization targets that must be achieved even in uncertain conditions using the WhatsApp learning tahsin and tahfidz applications SDIT Insan Madani continues to run, despite network constraints. Still, it turns out that the results obtained in this study conclude, there is a Covid-pandemic. 19 and other obstacles do not appear to affect the SDIT Insan Madani's tahsin and tahfidz programs' success. The results of this study are expected to provide examples and references for educational institutions, in particular, educational institutions that have excellent programs so that it is difficult to face how suitable methods are during the Covid-19 pandemic, can see and consider the ways of SDIT Insan Madani in keeping the learning going effectively.

\section{REFERENCES}

[1] Anwar, S. (2021) 'Internalisasi Nilai Pendidikan Akhlak dalam Surat Al-Hujurat Tafsir fi ZIlalil Qur' an', JIE: Journal of Islamic Edication, 6(1), pp. 1-12.

[2] Ariani, S. and Realita (2017) 'Program Bengkel Mengaji (Upaya Peningkatan Kemampuan Tahsin Al-Qur'an Mahasiswa PAI)', Jurnal Mudarrisuna - Media Kajian Pendidikan Agama Islam, 5(1), pp. 113-144.

[3] Arizona, K., Abidin, Z. and Rumansyah, R. (2020) 'Pembelajaran Online Berbasis Proyek Salah Satu Solusi Kegiatan Belajar Mengajar Di Tengah Pandemi Covid-19', Jurnal Ilmiah Profesi Pendidikan. doi: 10.29303/jipp.v5i1.111.

[4] Assingkily, M. S. (2019) 'Peran Program Tahfiz Dan Tahsin Al-Qur'an Dalam Meningkatkan Literasi Al-Qur'an Siswa Di Madrasah Ibtidaiyah Nurul Ummah Kotagede Yogyakarta', Jurnal MUDARRISUNA: Media Kajian Pendidikan Agama Islam. doi: 10.22373/jm.v9i1.4157. 
[5] Budiman, H. (2017) 'Peran Teknologi Informasi Dan Komunikasi Dalam Pendidikan', Al-Tadzkiyyah: Jurnal Pendidikan Islam. doi: 10.24042/atjpi.v8i1.2095.

[6] Cavus, N. (2015) 'Distance Learning and Learning Management Systems', Procedia - Social and Behavioral Sciences. doi: 10.1016/j.sbspro.2015.04.611.

[7] Ferdinan, F. and Ibrahim, M. (2018) 'Pelaksanaan Progam Tahfidz Al Qur'an (Studi Pesantren Darul Arqam Muhammadiyah Gombara Sulawesi Selatan)', TARBAWI : Jurnal Pendidikan Agama Islam. doi: 10.26618/jtw.v3i01.1379.

[8] Firdaos, R. and Ahmad, A. (2018) 'the Implementation of National Examination As the Direction of National Education Policy', Al-Tadzkiyyah: Jurnal Pendidikan Islam, 9(1), p. 135. doi: 10.24042/atjpi.v9i1.2788.

[9] Hamalik, O. (2005) 'Pengembangan Sumber Daya Manusia Manajemen Pelatihan Ketenagakerjaan Pendekatan Terpadu', in Proses Belajar Mengajar.

[10] Hasyim, B. (2013) 'Islam Dan Ilmu Pengetahuan (Pengaruh Temuan Sains terhadap Perubahan Islam)', Jurnal Dakwah Tabligh.

[11] Ikhwan, A. (2018) 'Management of Learning Assesment Using Curriculum 2013 (Case Study in Islamic Primary School (MI) Muhammadiyah 5 Wonoasri Ponorogo - East Java - Indonesia)', MUADDIB: Studi Kependidikan dan Keislaman, 08(02), pp. 108-123. doi: 10.24269/muaddib.v8i2.1422.

[12] Ikhwan, A. (2019) 'Public Relations in an Islamic Perspective ; Implementation Study at Madrasah', At-Turats: Jurnal Pemikiran Pendidikan Islam, 13(2), pp. 105-117. doi: https://doi.org/10.24260/at-turats.v13i2.996.

[13] Kemendikbud (2020) Mendikbud Luncurkan Empat Kebijakan Merdeka Belajar: Kampus Merdeka, Kementerian Pendidikan dan Kebudayaan.

[14] Moore, J. L., Dickson-Deane, C. and Galyen, K. (2011) 'E-Learning, online learning, and distance learning environments: Are they the same?', Internet and Higher Education. doi: 10.1016/j.iheduc.2010.10.001.

[15] Obeng, G. Y. (2013) 'Solar PV lighting and studying after sunset: Analysis of micro-benefits in off-grid rural Ghana', International Journal of Renewable Energy Development, 2(1), pp. 45-51. doi: 10.14710/ijred.2.1.45-51.

[16] Rusmanto (2020) 'Data wawancara', p. 2.

[17] Shodiq, I. J. and Zainiyati, H. S. (2020) 'Pemanfaatan Media Pembelajaran ELearning Menggunakan Whastsapp Sebagai Solusi Ditengah Penyebaran Covid19 Di Mi Nurulhuda Jelu', Al-Insyiroh: Jurnal Studi Keislaman. doi: 10.35309/alinsyiroh.v6i2.3946.

[18] Sudiarjo, A., Mariana, A. R. and Nurhidayat, W. (2015) 'Aplikasi Pembelajaran Ilmu Tajwid, Waqaf dan Makharijul Huruf Berbasis Android', Sisfotek Global.

[19] Sugiati (2016) 'Implementasi Metode Sorogan Pada Pembelajaran Tahsin Dan Tahfidz Pondok Pesantren', Qathrunâ.

[20] Suryani, D., Boy, E. and Ramadhani, F. Q. (2020) 'Edukasi Pencegahan Covid 19 Menyongsong New Normal Live Dengan Pendekatan Kedokteran Islam Pada Ibu- Ibu Salimah Deliserdang - Medan', Jurnal Implementa Husada, 1(2), p. 162. doi: 10.30596/jih.v1i2.5025. 
[21] Taopan, Y. F., Oedjoe, M. R. and Sogen, A. N. (2019) 'Jurnal Kependidikan':, Kependidikan.

[22] Widyastri, S. and Iskandar, I. (2020) 'Analisis Manajemen Lembaga Tahfidz dalam Meningkatkan Kualitas Bacaan Al-Qur'an Mahasisiwi IIQ Jakarta', Darul Ilmi: Jurnal Ilmu Kependidikan dan Keislaman. doi: 10.24952/di.v8i01.2700.

[23] Yuliana, Y. (2020) 'Analisis Keefektivitasan Pemanfaatan E-Learning Sebagai Media Pembelajaran Pendidikan Agama Islam Pada Masa Pandemi Corona (Covid-19)', SALAM: Jurnal Sosial dan Budaya Syar-i. doi: 10.15408/sjsbs.v7i10.17371. 